\title{
Phenolics Total and Antioxidant Activity of Strawberry (Fragaria chiloensis)
}

\author{
Rince Alfia Fadri, Salvia, Rilma Novita, Yenni Muchrida, Sri Kembaryanti Putri and Fidela Violalita

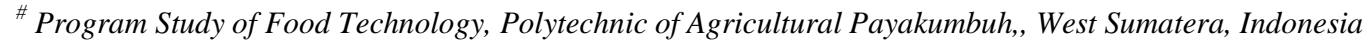 \\ E-mail: rince.alfia@yahoo.co.id
}

\begin{abstract}
The purpose of this research is to know the total of phenolics and antioxidant activity of Strawberry that grows in the area Alahan Panjang Solok Regency and Padang Panjang city. This research was carried out at the Chemical Laboratory of Agricultural Polytechinc State of Payakumbuh with a long six months time needed. To determine the levels of phenols total used Folin-Ciocalteu methode, and as a standard also to be used galat acid, while on antioxidant activity testing used DPPH free radical absorption methode. The results of research that methanol extract of Strawberries originally from Alahan Panjang have phenol total $180 \mathrm{mg} / 100$ $\mathrm{g}$ of fresh sample and higher than Strawberries originally from Padang Panjang with phenol total $139.2 \mathrm{mg} / 100 \mathrm{~g}$ of fresh sample.
\end{abstract}

Keywords - strawberry; phenolics total; antioxidant activity

\section{INTRODUCTION}

This document is a template. An electronic copy can be downloaded from the conference website. For questions on paper guidelines, please contact the conference publications committee as indicated on the conference website. Information about final paper submission is available from the conference website.

Strawberry (Fragaria chiloensis) originally an imported fruit, but now strawberries are very familiar in Indonesia. Many farmers are cultivating strawberries and some are merely a hobby at home. Strawberry production in West Sumatra reches 2,400 tons with a total area harvest 150 acres scattered across in the Alahan Panjang area, Padang Panjang, Batu Sangkar and Bukittinggi [1].

Strawberries have a high nutrient content and edible part of the strawberry reaches $96 \%$. In addition strawberries contain variety of essential nutrients, strawberries contain lycopene, anthocyanin, elagic acid, a phenolic compounds also vitamin $\mathrm{C}$ and vitamin $\mathrm{E}$ that are potentially as anti carsinogenic. Red on strawberry is the main pigment called anthocyanin [2]. But according to [3], red on strawberries is caused by licopene substance content in it. The number of active compounds that have characteristic as antioxidants in Strawberry make a well antioxidant network to ward off free radicals.

The function of Anthocyanin is as antioxidants in the body that can prevent the occurrence of hyper cholesterolemia [4]. In addition it also relaxes the blood vessels to prevent atherosclerosis and other cardiovascular diseases [5]. Lycopene plays a role in organizing cholesterol metabolism, by hampering the $H M G-C o A$ reduktase enzyme actions, which plays a role in the synthesis process of cholesterol in the liver,so it has hypocholesterolemi effect. From the research noted that the daily intake of $40 \mathrm{mg}$ likopen can reduce LDL oxidation [5].

The purpose of this research is to know the total of phenolics and antioxidant activity of Strawberry that grows in the area Alahan Panjang Solok Regency and Padang Panjang city.

\section{MATERIALS AND METHODS}

\section{A. Time and Place}

This research was carried out at the Chemical Laboratory of Agricultural Polytechinc State of Payakumbuh with a long six months' time needed.

\section{B. Tools and Materials}

The tools used are: Blender, filter paper Whatman No. 1, vaporizer cup, rotary evaporator, digital scales, measuring flasks,plate drops, measuring pipette, micro-pipette, spatel, aluminum foil, oven, desiccator, erlemeyer, watches, vial, measuring cup, funnel, test tubes, magnetic stirer, UV spectrophotometer set - Vis shimadzu 265.

The materials used are: Strawberries from Alahan Panjang and Padang Panjang, aquabidest acid, methanol, galat acid p.a (Merck), Reagent Folin-Ciocalteu, sodium carbonate p. a. 
(Merck), 2,2-diphenyl-1-pikrilhidrazil (DPPH) p. A (Merck), heksan p. a. (Merck), acetone (Merck), methanol, ethanol $96 \%$, vitamin C.

\section{Research Design}

The design used was experimental research in vitro laboratoriy that aim to measure the total phenols and the activities of methanol extracts of Strawberry from two regions, Alahan Panjang Solok Regency and Padang Panjang city.

\section{Research Implementation}

To determine the levels of phenols total used FolinCiocalteu methode, and as a standard also to be used galat acid, while on antioxidant activity testing used DPPH free radical absorption methode.

\section{E. Sampling}

The sample used is strawberry, which were taken in the area Alahan Panjang Solok Regency and from Padang Panjang City.

\section{F. Sample Prepaation}

$250 \mathrm{~g}$ of fresh strawberries weighed, blender for 3 minutes and then maceration with $250 \mathrm{ml}$ of methanol, while shaked. Do for 3 repetitions then filter by using filter paper whatman No. 1, mixing it with the filtrate. The filtrate is thicked by using a rotary evaporator, so the extracts that can be poured obtained.

\section{G. Determination of Phenolic Total Content by Folin- Ciocalteu Method Scrambled, h. h., 2006. [6]}

From The prime of Galat Acid solution $(5 \mathrm{mg} / \mathrm{ml})$, taken by pipette tes $1,1.5,2,2.5,3,3.5 \mathrm{ml}$ and to be diluted with aquadest to volume $25 \mathrm{ml}$. so that the concentration to be resulted are 200, 300, 400, 500,600, and $700 \mathrm{mg} / \mathrm{L}$ galat acid. By each concentration above,taken by pipette tes 0,2 $\mathrm{ml}$ added $15.8 \mathrm{ml}$ of aquadest added $1 \mathrm{ml}$ Folin Ciocalteu Reagent and to be shaked. Let it for 8 minutes, add $3 \mathrm{ml}$ of $20 \%$ solution of $\mathrm{Na} 2 \mathrm{CO} 3$ and shake until homogeneous. Let it for 2 hours at room temperature. Measure the absorption at amaximum wavelength absorption $765 \mathrm{~nm}$, and create its calibration curve the relationship between concentration of galat acid (mg/L) and absorbance.

Sample (Strawberry extract) first diluted with $10 \mathrm{ml}$ of aquadest, then to be taken by pipette test $0,2 \mathrm{ml}$ and $15.8 \mathrm{ml}$ of aquadest added. Then add $1 \mathrm{ml}$ of Folin-Ciocalteu reagent and shaked. Let it for 8 minutes then add $3 \mathrm{ml}$ of $20 \%$ $\mathrm{Na} 2 \mathrm{CO} 3$ to the mix, let the solution stands for 2 hours at room temperature. Measure its absorbtion with UV-Vis spectrophotometer at a absorption wavelength maximum $765 \mathrm{~nm}$ which will provide complex blue. Do 3 repetitions so that levels of phenols obtained, the result obtained as $\mathrm{mg}$ equivalent galat acid/L.

\section{H. Examination Of Antioxidant Activity [7][8]}

$10 \mathrm{mg}$ of extract to be weighed, then dissolve in $10 \mathrm{ml}$ of methanol in measurement flask ad $10 \mathrm{ml}$, so, found a concentration of $1 \mathrm{mg} / \mathrm{ml}$. then do the dilution by adding methanol thus samples with concentrations $(20,40,60$, 80,100 glow g/ml) obtained.
For the determination of antioxidant activity of each concentration to be taken by pipette test as much as $0.2 \mathrm{ml}$ of the sample solution with a micro pipette and input into the vial, then add $3.8 \mathrm{ml}$ of solution DPPH $50 \mu \mathrm{m}$. The compound to be homogeneous and left for 30 minutes in a dark place, the absorption is measured by UV-Vis spectrophotometer at a wavelength of $515 \mathrm{~nm}$.

\section{Determination Of The Dpph Maximum Wavelength Absorption [8]}

$3.8 \mathrm{ml}$ of solution DPPH $50 \mu \mathrm{M}$ taken by pippette test and add with a $0,2 \mathrm{ml}$ of methanol. After 30 minutes left in a dark place, absorption solution to be measured by UV-Vis spectrophotometer at a wavelength of $400-800 \mathrm{~nm}$.

\section{J. Data Processing}

Antioxidant activity of samples is determined by the size of the radical DPPH obstacle through calculation of the inhibition percentage of DPPH absorption by using the formula:

\section{$\%$ inhibition $=\frac{\text { AbsControl }- \text { AbsSample } \times 100 \%}{\text { AbsControl }}$}

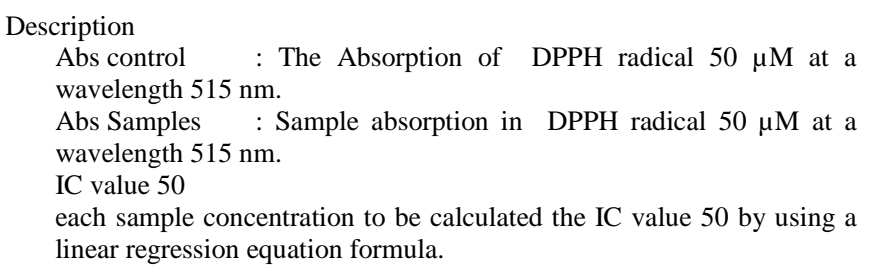

\section{RESULTS AND DISCUSSIONS}

The extraction is done by maceration because the way is easily done at room temperature and using simple tools in a way the samples soaked in the solvent. The solvent used was methanol because it can dissolve almost all organic compounds in the samples mainly polar compound. Methanol easily evaporate so it liberated from the extract easily, and disposed cheaper compared to other organic solvents. All the filtrate obtained from extraction results to be evaporated with the rotary evaporator so that the strawberries methanol extracts obtained that can be poured as much as 11: 57\% (Strawberries from Padang Panjang) and $7.74 \%$ (Strawberries from Alahan Panjang) from the initial weight of each.

Determination levels of phenols total used as galat acid as standard solution. The maximum galat acid absorption is obtained at a wavelength $768 \mathrm{~nm}$. By the time the examination of the levels of phenols total strawberries done, firstly made the calibration curve galat acid standard solutions with a concentration series 200-700 mg/l. Making this calibration curve is useful to help determine the levels of phenol in the sample through the equation of regression of the calibration curve. From an examination of the standard galat acid solution the calibration curve obtained by a regression equation $\mathrm{y}=0.000979 \mathrm{x}+0.03455$ and coefficient correlation(r) price that is 0.998. On the determination of the levels strawberries phenolat total from Strawberry extract of Alahan Panjang value obtained $232.6694 \mathrm{mg} / \mathrm{L}$ and The levels of Padang Panjang Strawberry Phenolat total extract value obtained 120.3098 
mg/l. This value equal to the Alahan Panjang Strawberry phenolat total level $1800.219 \mathrm{mg} / \mathrm{kg}$ of fresh samples and Padang Panjang strawberry phenolat total $1392.502 \mathrm{mg} / \mathrm{kg}$ of fresh samples. This result shows that the Strawberries originally from Alahan Panjang have phenol total 180 $\mathrm{mg} / 100 \mathrm{~g}$ of fresh sample and higher than the Strawberries originally from Padang Panjang with phenol total 139.2 $\mathrm{mg} / 100 \mathrm{~g}$ of fresh sample. According to ${ }^{[8]}$ strawberries phenol total range between $43-94 \mathrm{mg} / 100 \mathrm{~g}$ of fresh weight and $202-275 \mathrm{mg} / 100 \mathrm{~g}$ of fresh weight.

TABLE I

ABSORB ANCE MEASUREMENT RESULTS OF STANDARD GLATACID SOLUTION AT A WAVELENGTH 765 NM WITH UV-VIS SPECTROPHOTOMETER

\begin{tabular}{|l|l|}
\hline Galat Acid Concentrate (ppm) & \multicolumn{1}{|c|}{ Absorbance Values } \\
\hline 200 & 0.217 \\
\hline 300 & 0.326 \\
\hline 400 & 0.445 \\
\hline 500 & 0.534 \\
\hline 600 & 0.621 \\
\hline 700 & 0.707 \\
\hline
\end{tabular}

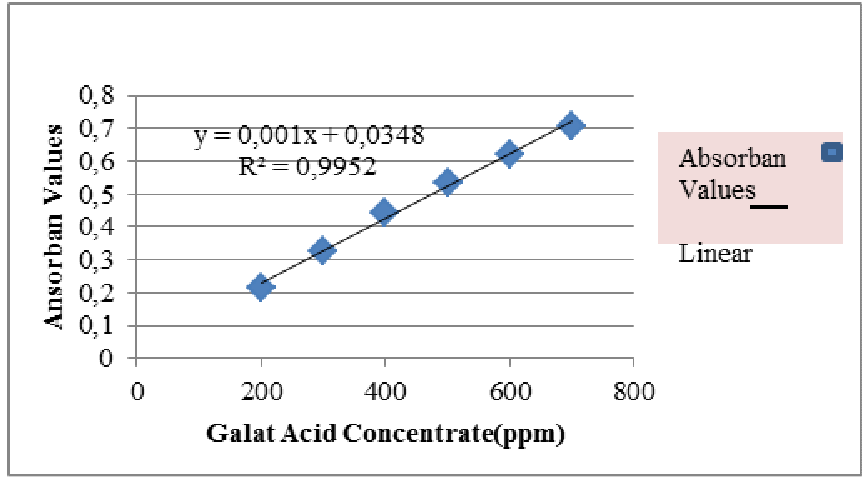

Fig.1 Galat acid calibration curve in folin-Ciocalteu reagent at a wavelength $768 \mathrm{~nm}$

The method used in testing antioxidant activity was radical DPPH absorption method. Measurement of sample antioxidant activity done at a wavelength $515 \mathrm{~nm}$ which is the the maximum DPPH wavelength, with concentration of DPPH $50 \mu \mathrm{m}$. Antioxidant activity of the samples caused discoloration of DPPH solution in methanol that originally strong violet into a pale yellow.

Antioxidant activity of Strawberry methanol extract expressed in its percent inhibition against DPPH radical. Percentage of inhibition obtained from the difference absorbance between DPPH absorbance with sample absorbance that measured with a spectrophotometer UV_Vis. The amount of antioxidant activity marked by IC 50, that is the concentration of the sample solution is needed to inhibit 50\% DPPH free radical. Antioxidant activity Test using the DPPH method of strawberries methanol extracts from Alahan Panjang and Padang Panjang concentration 20,40, 60, $80,100 \mu \mathrm{g} / \mathrm{ml}$, it is obtained IC 50 each 152,9 and 232,6 $\mu \mathrm{g} / \mathrm{ml}$. Whereas the value of the IC 50 of vitamin C is 3.63 $\mu \mathrm{g} / \mathrm{ml}$ to the DPPH $50 \mu \mathrm{M}^{[10]}$. This indicates that Strawberries extract originally from Alahan Panjang have better antioxidant activity than strawberries extract originally from Padang Panjang. But the antioxidant activity of vitamin C is far higher. Molyneux (2004) Stated that a substance has antioxidant characteristic when the value of the IC50 less than $200 \mathrm{ppm}$. When the value of the IC50 ranging between 200-1000 ppm, then the substance is less active but still has potential as antioxidant. Strawberry antioxidant activity test results can be seen in table and picture 1 .

TABLE II

STRAWBERRIES EXTRACT METHANOL ANTIOXIDANT ACTIVITY USING THE DPPH $50 \mu \mathrm{M}$

\begin{tabular}{|lcccc|}
\hline $\begin{array}{c}\text { Compa- } \\
\text { Rator }\end{array}$ & $\begin{array}{c}\text { Concen- } \\
\text { tration }\end{array}$ & Absorbancecy & $\begin{array}{c}\text { \% } \\
\text { Inhibition }\end{array}$ & $\begin{array}{c}\text { IC50 } \\
(\boldsymbol{\mu g} / \mathbf{m l})\end{array}$ \\
\hline Padang & 20 & 0,227 & 0,3204 & \\
Panjang & & & & \\
Strawberry & 40 & 0,216 & 0,3533 & \\
(PP) & 60 & 0,213 & 0,3623 & 232,6 \\
& 80 & 0,208 & 0,3772 & \\
& 100 & 0,204 & 0,3892 & \\
\hline Alahan & 20 & 0,231 & 0,4238 & \\
Panjang & & & & \\
Strawberry & 40 & 0,230 & 0,4250 & 152,9 \\
(AP) & 60 & 0,228 & 0,4300 & \\
& 80 & 0,220 & 0,4500 & \\
& 100 & 0,210 & 0,4750 & \\
\hline Vitamin C & 2 & 0,132 & 20,09 & \\
& 3 & 0,235 & 42,82 & \\
& 4 & 0,189 & 54,01 & 3,63 \\
& 5 & 0,123 & 70,07 & \\
& 6 & 0,065 & 84,18 & \\
\hline
\end{tabular}

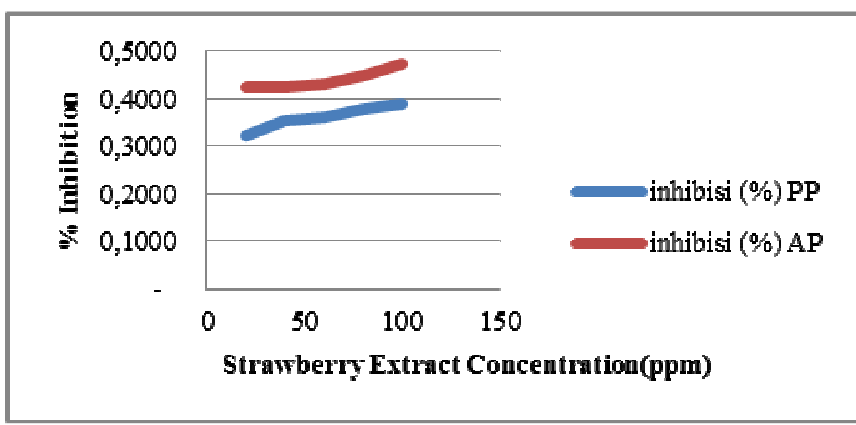

Fig.2 Strawberry extract anti oxidant activities curve

\section{CONCLUSIONS}

From the results of research that has been done can be taken the following conclusions: The methanol extract of Strawberries originally from Alahan Panjang have phenol total $180 \mathrm{mg} / 100 \mathrm{~g}$ of fresh sample and higher than Strawberries originally from Padang Panjang with phenol total $139.2 \mathrm{mg} / 100 \mathrm{~g}$ of fresh sample. The methanol extract of Strawberries originally from Alahan Panjang and Padang Panjang have the ability to muffle DPPH free radical but smaller than the ability of vitamin C $(3.63-\mu \mathrm{g} / \mathrm{ml})$. IC 50 value of Strawberry extract originally from Alahan Panjang is $152,9 \mu \mathrm{g} / \mathrm{ml}$ whereas IC 50 value of Strawberry extract from Padang Panjang is $232,6 \mu \mathrm{g} / \mathrm{ml}$. 


\section{REFERENCES}

[1] Central Bureau of Statistics, Census of Agriculture Province of West Sumatra , Padang , 2013

[2] Gould, Kevin, M., Winefield, Antocyanins, Springer, 2008

[3] Astawan M \& T Wresdiyati. Healthy diet with fibrous food . Solo, Three Musketeers, 2004

[4] Fadri, R. A., 2010. Efek Pemberian Sari Stroberi Terhadap Kadar Kolesterol Darah Tikus Putih (Rattus norvegicus) Hiperkolesterolemi, Tesis. Universitas Andalas. Padang

[5] Houghton, J.D, 2001."Effect of Cholesterol- Lowering therapy on Endothelial Fuction". Proffesor of Medicine, Albany Medical College. Albany.

[6] Marimuthu, P.; Wu, C.-L.; Chang, H.-T.; Chang, S.-T. Antioxidant activity of the ethanolic extract from the bark of Chamaecyparis obtusa var. formosana. J. Sci. Food Agric. 2008
[7] Hanani, E., A. Mun'im, and R. Sekarini. 2005. Identification of Compounds Antioxidants In Callyspongia Sponge SP From the Thousand Islands, Magazines Pharmaceutical Sciences, Vol II , No. 3 (2005) . Page 127-133

[8] Okawa, M., J. Kinjo, T. Nohara and M.ono, 2001, Modification Method "DPPH (2-2-difenil-1-pikrilhidrazil) Radical Scavenging Activity Of Flavonoids Obtained From Some Medicinal Plants. Biol. Pharm. Bul., 24 (10), 1202

[9] Howard, L. R and T. J. Hager. 2007. "Berry Fruit Phytochemicals" in Berry Fruit, CRC Press. chapter 3, p. 90

[10] Andayani , R. , Y. Lisawati and Maimunah . 2008. Determination of antioxidant activity, total phenolic concentration and lycopene in tomatoes ( Solanum lycopersicum L ). Journal of Pharmaceutical Science and Technology, Vol . 13, No. 1, 2008 